\title{
In memoriam Peter Boomgaard
}

\author{
David Henley \\ Leiden University \\ d.e.f.henley@hum.leidenuniv.nl
}

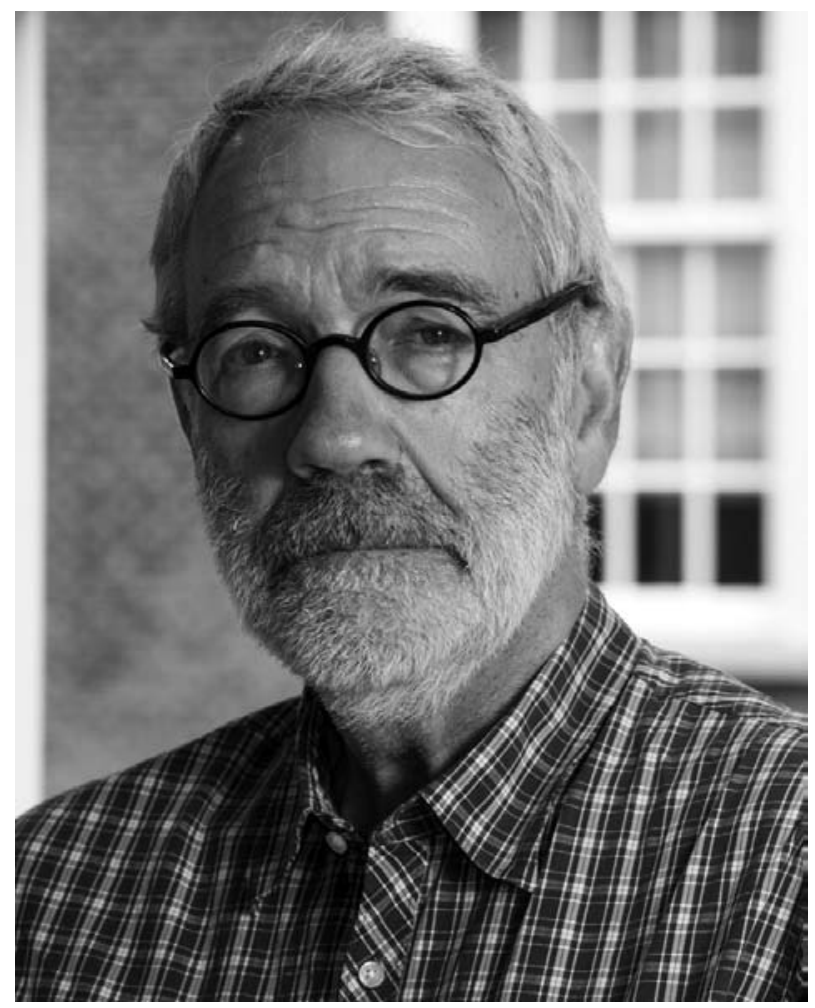

On Tuesday 10 January 2017, Peter Boomgaard, distinguished historian of Indonesia and former director of the Koninklijk Instituut voor Taal-, Land- en Volkenkunde / Royal Netherlands Institute of Southeast Asian and Caribbean Studies (KITLV), died aged 70 in Amsterdam after a protracted struggle with the consequences of a cardiac arrest which he had suffered the previous October. He is survived by his widow Raquel (Raquel A.G. Reyes, historian and newspaper columnist), by his sons Pim (Willem Steven, architectural conservationist)

(C) DAVID HENLEY, 2017 | DOI: 10.1163/22134379-17302005

This is an open access article distributed under the terms of the prevailing CC-BY-NC license at the time of publication. 
and Cosmo (five years old, aspiring paleontologist), and by his stepdaughter Gaia (currently studying at Cambridge University). Many scholars of Southeast Asia in the Netherlands attended Peter's funeral in Amstelveen on 19 January, and on 16 February a day-long memorial seminar was held for him in Yogyakarta, Indonesia, under the auspices of Universitas Gadjah Mada, the KITLV, Leiden University, and two professional organizations of Indonesian historians.

Peter was born on 6 November 1946 in The Hague, where his father worked for the trades union federation $\mathrm{CNV}$ and his mother as a teacher. Although agnostic throughout his adult life, he was strongly influenced by the austere Protestant (Dutch Reformed Church) religious culture of his childhood. His early education and interests were extremely broad, laying the foundations for a lifetime of intellectual eclecticism. At grammar school in Amsterdam, where his family moved when he was six, he chose to study a full natural science curriculum alongside the standard six languages: Dutch, Latin, Greek, French, German, and English. In his spare time he also took Spanish lessons and read many classic novels, which his father insisted he should do only in their original languages. As an adult he remained a voracious and omnivorous reader, with a book collection that fairly dominated his successive homes. For light entertainment he enjoyed reading thrillers, and long harboured an ambition to write one himself. For exercise and in order to think, he liked to cycle through the surprisingly empty and elemental landscape of dunes and woods that runs along the coast of Holland between the geometric polders and the wild North Sea.

On finishing school in 1964, Peter hesitated briefly between history and economics before choosing to study history at the Vrije Universiteit Amsterdam. As a student he became interested, like many critically minded students of the time, in Latin America, and in 1970 spent several months in Mexico doing research for his MA thesis on the economic and demographic background to the Mexican revolution. Following a brief initial academic appointment at the Nederlandse Economische Hogeschool (Netherlands School of Economics, forerunner of the Erasmus Universiteit in Rotterdam), where he investigated the history of the Dutch labour movement, Peter returned to the Vrije Universiteit Amsterdam in 1973 as researcher and junior lecturer in economic and social history and non-Western history. Here he was persuaded to put aside his Latin American interests and immerse himself in the history of Indonesia.

Part of the reason for this change of direction was that with so many relevant source materials available in the Netherlands, Indonesia was an easier specialization than Mexico to combine with intensive teaching duties. A first visit to Indonesia in 1976 confirmed his interest in that country. Another factor was a lively academic debate, initiated by Dutch sociologists Jan Breman and Bram 
Peper, then ongoing over the magnitude and causes of the growth of Java's population in the nineteenth century. This debate alerted Peter to the importance and potential of colonial Java as a case study in demographic change, which duly became his $\mathrm{PhD}$ project under the supervision of Indonesianist Heather Sutherland. The ultimate result was the publication in 1989 of his standard work Children of the colonialstate: Population growth and economic development in Java, 1795-1880. Partly as a spinoff from this research, he also became involved in editing the monumental Koninklijk Instituut voor de Tropen (Royal Tropical Institute, KIT) statistical publication series Changing Economy in Indonesia, initiated in the 1970 s by Piet Creutzberg.

In 1991 Peter was appointed director of the KITLV in Leiden, where he initiated, led, and coordinated the EDEN (Ecology, Demography and Economy in Nusantara) research project on the environmental history of Indonesia. In 1994 he was also made honorary professor of environmental and economic history of Southeast Asia at the University of Amsterdam. Stepping down as director in 2000 in order to devote himself more fully to research and writing, he remained a productive and dynamic senior researcher at the KITLV until his formal retirement in 2011. During this period he also spent time as a visiting fellow at the Massachusetts Institute of Technology, on the invitation of historian of human-animal relations Harriet Ritvo, and at Yale University, on the invitation of historian of Southeast Asia James Scott.

After his retirement Peter continued to be in international demand as a researcher. On the recommendation of leading American environmental historian John McNeill, he was awarded a senior fellowship at the Rachel Carson Center for Environment and Society in Munich (2012-2013). A year later he was named Fernand Braudel Fellow at the European University Institute in Florence (2013-2014). Whenever he was not sojourning abroad, he continued to be seen on a regular basis at his desk in Leiden until 25 October 2016, the day before his cardiac arrest.

Peter was one of the most distinguished historians of Southeast Asia, in his own or any generation. He lives on in a huge academic legacy of important and inspiring written works. Besides three books of his own, he edited or co-edited no fewer than sixteen collective volumes and produced more than 120 published articles and chapters-particularly impressive considering that much of this output occurred during the period of his directorship of the KITLV. The range of topics on which he published was very wide. In the field of historical demography he not only produced the definitive study of nineteenthcentury Java, but also wrote more broadly on the subjects of fertility, birth control, disease, and medicine, making key contributions to the debate over the causes of low population growth in precolonial Southeast Asia, and of the 
subsequent population boom. In relation to economic history he contributed writings on monetization, credit and debt, business cycles, state welfare services, land tenure, and the economic consequences of bonded labour. His most prominent research role, however, was in the field of environmental history.

It is hardly too much to say that Peter single-handedly pioneered the study of the environmental history of Indonesia-through the EDEN project and other endeavours in the organizational and fundraising sphere, but above all through his own research and the example which it set. His publications in this area included two major monographs: the only book to date on the historical relationship between tigers and people, Frontiers of fear: Tigers and people in the Malay world, 1600-1950 (2001), and the only comprehensive textbook to date on the environmental history of the Southeast Asian region as a whole, Southeast Asia: An environmental history (2007). At the time of his death he was working on a further book, dealing with forests and forestry in Java from 1500 to 1950. Among his many articles and chapters on environmental history topics, particularly widely cited have been those exploring the histories of forestry, nature conservation, and non-rice food crops in Indonesia.

A richly empirical scholar, Peter had a traditional sense of thoroughness and attention to detail. His publications are mines of well-ordered information, which can often be used to generate hypotheses quite different from those which he himself advanced in relation to them. He sometimes expressed a refreshing, albeit frustrating, scepticism toward big ideas which he believed could not yet be placed on a firm empirical foundation. One of the most surprising things about Southeast Asia: An environmental history, for example, is the short shrift which it gives to climate change as a historical influence. Other historians have not hesitated to link the rise and fall of Angkor in Cambodia with climatic changes paralleling those of the Medieval Warm Period in Europe, and the 'seventeenth-century crisis' in Indonesia with an Asian counterpart to the European Little Ice Age. Peter, by contrast, discusses these ideas only briefly and - in his own words - 'with some trepidation', arguing that in order to test them 'we need information of a much more detailed nature, and given the nature of Southeast Asian historical sources, I am not certain that we will ever get it'.

Yet Peter also possessed that ability not to miss the wood for the trees, and to distinguish between an important and a less important fact, which is the mark of the true scholar. Many of his research findings were unexpected and trail-blazing. He was, for instance, among the first researchers to emphasize the importance of low fertility, alongside high mortality, to the low population growth rates of precolonial Indonesia. He showed how traditional methods of fertility control, including contraception and abortion, kept birth rates low, 
and how traditional social institutions such as bridewealth and slavery created incentives for women to restrict their fertility using those techniques. In another counterintuitive insight he demonstrated that Java de-urbanized under colonial rule, with the proportion of its population living in towns falling rather than rising in the course of the nineteenth century, whereas the reverse had usually been assumed. In Frontiers of fear he highlighted the intriguing fact that tigers, in Southeast Asia, were not creatures of the natural forest, but thrived where human action created open landscapes rich in large prey animals like deer and pigs. This meant that tigers were effectively symbiotic with people, and for a long time their numbers rose rather than declined as human populations grew.

Perhaps because of his early schooling in natural science, Peter had no fear of statistics and often used quantitative data and methods in his work. But this is not to say that he dealt only in statistical abstractions. Indeed, a look at his publications list reveals a trademark interest in the earthy, the visceral, even the sinister side of Southeast Asian history: leprosy and syphilis, cockfighting and tiger-baiting, bestiality and incest. These were intensely human areas of interest, and his treatment of them reflected an anthropological as well as a historical sensibility. Peter was in fact exemplary in his concern to integrate ethnography, folklore, and anthropological insights into his historiography. This was already apparent in his early work on fertility patterns and birth control in Java, and reached a new level in Frontiers of fear, whole chapters of which are devoted to 'ancestral tigers', were-tigers, and the tiger rituals of the Javanese courts. Toward the end of his life his interest in individual experience and behaviour in history strengthened under the influence of his wife Raquel, who encouraged him to tackle new themes such as sexual diversity and the sensory environment.

Yet Peter remained, perhaps above all, a scholar with an eye for the big picture. Deeply inspired by the work of the great French historian Fernand Braudel, who made the concept of the longue durée common currency among historians everywhere, he was a great enthusiast for long time frames, resulting in awe-inspiring yet faintly amusing Boomgaard article titles like 'Economic growth in Indonesia, 500-1990'. If called upon to write on a narrower topic, he would sometimes compensate by covering an even longer timespan, as in the case of a 2008 essay on the use of cowry shells as currency, which spanned a cool two and a half millennia, from 600 вСE to $1900 \mathrm{CE}$. It was not for nothing that the theme of the conference held to mark Peter's retirement in 2011 was 'Southeast Asia: The Longue Durée', and that the festschrift published as a result of that conference is titled Environment, trade and society in Southeast Asia: $A$ longue durée perspective (2015). 
The other crucial aspect of Peter's panoptic perspective on Southeast Asian history was his ability to make informed connections with developments elsewhere in the world. He had begun his research career, as noted, in Mexico, only later switching his attention to Indonesia, in a move which left him with a better feel for international comparisons and universal principles than most Southeast Asia specialists possess. Moreover, his academic background in Amsterdam, with its tradition of leftist social history, rather than Leiden, with its cultural interests and its colonial tradition of 'Indology', made him more at home with such things as W.F. Wertheim's comparative sociological work on 'East-West parallels', and Immanuel Wallerstein's 'world systems theory', than with the orientalism of pre-war Dutch scholars like Cornelis van Vollenhoven and J.H. Boeke. In the concluding chapter of Southeast Asia: An environmental history he relates the region's current ecological problems less to geographically and culturally specific factors, or to colonial legacies as such, than to Southeast Asia's persistent status as part of the exploited 'periphery' or 'semi-periphery' of the global economy as defined in the Wallerstein model.

No historical topic could be of greater relevance to contemporary Southeast Asia than man's changing relationship with the natural environment. The region's status as earth's richest reserve of biodiversity, combined with its dense human population and rapid economic development, puts it at the very centre of the global struggle to protect nature. In this connection Peter noted the positive implications of the region's continuing demographic transition (that is, the transition to lower birth rates). Toward the end of his life he also became interested in evidence for an incipient 'forest transition' - that is, a decline in the rate of deforestation, historically also seen in Western countries once they reached a certain level of economic development-in the Philippines, Thailand, and Vietnam (though not yet, regrettably, in Indonesia). But on the whole Peter was much more concerned - and legitimately so, as a historianwith documenting Southeast Asia's ongoing environmental disasters than with looking for glimmers of hope in the form of evidence for positive change, or potentially useful historical lessons for contemporary conservation practice. These remain urgent tasks for younger generations of historians, and tackling them is one way in which we can and should build constructively on Peter's legacy.

Peter Boomgaard is sadly missed. Despite his untimely death, his influence on the scholarly world will continue to be strong for a very long time to come. It is telling that many young Indonesian academics participated in his memorial seminar in Yogyakarta, and that even those contributors who had never met him in person showed themselves to be genuinely informed and inspired by his work. Peter was a pioneer, a pathfinder who mapped out new fields and lines of 
historical inquiry. Just as importantly, he demonstrated by example how much can be achieved by pursuing those lines of inquiry, even using labyrinthine colonial archive materials not designed or structured for the purpose. To do this well requires a sharp intellect, an open mind, a formidable work ethic, and a familiarity with diverse fields of knowledge. But such are the challenges facing historians of Indonesia and Southeast Asia, and Peter proved that it is humanly possible to meet them. 